OPEN ACCESS

Edited by:

Ana Rainho,

University of Lisbon, Portugal

Reviewed by:

Bruce D. Patterson,

Field Museum of Natural History,

United States

Robert W. Myslajek,

University of Warsaw, Poland

${ }^{*}$ Correspondence:

Eric-Moîse BakwoFils filsbkw27@gmail.com

Manga Aaron Mongombe

mangajes@gmail.com

${ }^{\dagger}$ These authors share first authorship

Specialty section: This article was submitted to Conservation and Restoration

Ecology,

a section of the journal

Frontiers in Ecology and Evolution

Received: 20 August 2021 Accepted: 03 November 2021 Published: 02 December 2021

Citation:

BakwoFils E-M, Mongombe MA, Manfothang DE, Gomeh-Djame A, Takuo JM and Bilong BCF (2021)

Patterns of Bat Diversity in an Undisturbed Forest and Forest Mosaic Habitats of the Afromontane Forest Biome of Western Cameroon.

Front. Ecol. Evol. 9:761969. doi: 10.3389/fevo.2021.761969

\section{Patterns of Bat Diversity in an Undisturbed Forest and Forest Mosaic Habitats of the Afromontane Forest Biome of Western Cameroon}

\author{
Eric-Moîse BakwoFils ${ }^{1 * t}$, Manga Aaron Mongombe ${ }^{1 * t}$, Dongmo Ervis Manfothang ${ }^{2}$, \\ Aicha Gomeh-Djame ${ }^{3}$, Jean Michel Takuo ${ }^{4}$ and Bilong Charles Felix Bilong ${ }^{3}$ \\ ${ }^{1}$ Department of Biological Sciences, Faculty of Sciences, University of Maroua, Maroua, Cameroon, ${ }^{2}$ Faculty of Agronomy \\ and Agricultural Sciences, University of Dschang, Dschang, Cameroon, ${ }^{3}$ Department of Animal Biology and Physiology, \\ University of Yaoundé I, Yaoundé, Cameroon, ${ }^{4}$ Environnement, Recherche, Développement, Yaoundé, Cameroon
}

Anthropogenic activities continue to degrade natural montane ecosystems globally. Bats communities are altered by these changes. We analyzed how bats are affected by human-induced habitat changes by comparing the bat species diversity and functional diversity in undisturbed forest habitats and disturbed forest habitats of the Afromontane biome of Cameroon. We recorded 244 individuals from 13 species in the undisturbed forest, while 233 individuals from 16 species were recorded in the disturbed forest. Bat diversity was higher in disturbed habitats $(D=0.84)$ than undisturbed habitats $(D=0.67)$. Jackknife 1 species richness estimator suggests 21.53 species for the disturbed forest and 19.30 in the undisturbed forest. Closed-space forager insectivorous bats made up nearly half of the species in the undisturbed forest, but this dropped to $25 \%$ in the disturbed forest, meanwhile, edge-space foragers increased in the disturbed forest. Bat community analyses by ordination revealed a distinct bat community composition between the two forest types, demonstrated as a significant difference in diversity between the two forest types. The distribution of Rousettus aegyptiacus, Myonycteris angolensis, Hipposideros cf. ruber, and Micropteropus pusillus contribute the most to the difference in bat community composition between the two forest types. Edge and open-space species were likely to benefit from additional resources provided by the disturbed area, by expanding their range and distribution. However, this may not compensate for the decline in the population of forest species caused by the loss of pristine forests, thus measures to conserve montane forest remnants should be of utmost significance.

Keywords: edge species, bats, human activities, undisturbed forest, disturbed forest

\section{INTRODUCTION}

The biota of the tropical montane forest is very diverse and varied in endemic species (Gentry, 1995; Kessler and Kluge, 2008). These ecosystems are also amongst the most threatened globally (Hamilton et al., 1994; Doumenge et al., 1995), with the estimated rate of deforestation nearly double the rate of average global deforestation rates in the past few decades (Hamilton et al., 2012). 
Threats emanate from human activities such as the uphill expansion of shifting cultivation and the exploitation of natural resources. In Africa, the situation is further exacerbated by extreme poverty that drives the immigration of subsistence farmers into the montane forest from adjacent lowland areas (Körner and Ohsawa, 2006; Mugagga et al., 2012). Indeed, tropical moist forests are estimated to have reduced by half of their original distribution in the last two decades due to agricultural activities (Myers, 1991; Gibbs et al., 2010). Given the accentuating nature of these threats, tropical forests are a conservation priority globally (Edwards et al., 2019).

The Afrotropical Highlands biome of Cameroon that encompasses the highlands of western Cameroon contain large forested areas that harbor unique ecological and biological diversity across many taxa (Myers et al., 2000; Olson et al., 2001; Oates et al., 2004). The biome covers the western highlands of southwestern Cameroon and extends northeast to the Obudu and Mambilla Plateaus in Eastern Nigeria. The unique diversity and endemism in this biome are thought to be a result of the area being a major refugium during the Quaternary glaciation (Stuart, 1986; Lawson, 1993; Stattersfield et al., 1998; Myers et al., 2000). This rich diversity has also been attributed to the region's wide variety of habitats resulting from its extensive highlands (Cronin et al., 2014). Indeed the montane forests of the Cameroon Highlands are considered a priority area for conservation globally (Myers et al., 2000), this results from the area's high biodiversity and endemism (Maisels et al., 2001; Oates et al., 2004; Linder and Oates, 2011; Abernathy et al., 2013; Cronin et al., 2014). However, despite such important features, very few parts of the highland's habitats are currently under formal protection status in Cameroon, which poses a challenge to its conservation (Bergl et al., 2007). Moreover, except for Mount Cameroon, these montane forests have been significantly degraded by human activities (Collar and Stuart, 1988; Gartlan, 1989; Alpert, 1993; Megevand et al., 2013), and most often comprise only forest fragments within montane grasslands grazed by cattle of the Fulani herdsmen (Ineich et al., 2015).

One way to mitigate the adverse effects of human activities in an ecosystem is the establishment of protected areas (Geldmann et al., 2013). Protected areas harbor higher species diversity than unprotected areas (Laurance et al., 2012; Geldmann et al., 2013; Gray et al., 2016), resulting from the reduction in human-induced land-use changes such as poaching, wildfires, and deforestation (Geldmann et al., 2013; Barber et al., 2014; Gray et al., 2016). Indeed, Razgour et al. (2020) pointed out that anthropogenic land-use changes are associated with a severe decline in the population of some Afromontane bat species. Unfortunately, most of the biodiversity hotspot of the Afromontane biome of Cameroon is devoid of any legal protection. Consequently, decades of intensive anthropization have reduced formerly continuous montane forests to isolated fragments, cultivated landscapes, grassland, human settlements, and industrial plantations.

Bats play an important role in tropical forest succession after disturbance. Frugivorous and nectarivorous bat species can explore a wide range of resources, providing several ecological services such as pollination, seed dispersal, and forest regeneration (Stevens et al., 2004; Willig et al., 2007). Additionally, insectivorous bats are important suppressors of agricultural pest insects (Kalka et al., 2008; Jones et al., 2009). In addition, because of their high species richness, abundance, and variety of functional guilds bats are considered as a good bioindicator taxon used to study various human-induced alterations of ecosystems, such as forest fragmentation and degradation (Jones et al., 2009; Meyer et al., 2010). Furthermore, sensitivity to habitat fragmentation can be attributed mainly to species-specific mobility-related traits (Law et al., 1999; Farneda et al., 2015; Moir et al., 2021).

Previous records of bats in the Cameroon Highlands were mostly in the form of pioneer faunistic expeditions and collection of specimens (Eisentraut, 1942, 1956, 1963, 1964, 1968, 1973; Hill, 1968; Fedden and MacLeod, 1986). Recently, surveys by Mongombe et al. (2019, 2020), Manfothang et al. (2020, 2021) added some recent information about bats of the Cameroon Highlands. However, none of these studies evaluated the effect of anthropogenic activities on bat diversity in the biome.

Several studies in a variety of biomes and taxa have revealed that the number of species that inhabit remnant patches of forest decreases significantly as habitat patch size decreases (Debinski and Holt, 2000; Devictor et al., 2008). Habitat fragmentation, because of agricultural activities is known to alter bat assemblages (Walsh and Harris, 1996; Cleary et al., 2016). However, the response of bat communities to fragmentation can be positive or negative depending on whether the bat species is a specialist or a generalist. Some generalists can better persist in anthropogenically altered environments due to the ability to exploit additional resources such as man-made habitats (secondary vegetation and cultivated farms) and food resources (Coleman and Barclay, 2012). On the other hand, habitat fragmentation can reduce bat species richness and abundance by reducing roosts and the availability of resources (Schulze et al., 2000). Even though the montane forest of the Cameroon Highlands continues to diminish because of significant human pressure, our knowledge on changes in bat communities induced by anthropogenic activities and how human activities affect bat diversity in the area is still limited. This data is imperative to predict the long-term consequences of fragmentation on the montane forest biodiversity and to mitigate any effects. Therefore, there is a need to collect such scientific information in the area before the opportunities diminish completely due to the ever-accelerating deforestation in the region. Determining the species that either become extinct or can persist in disturbed areas is crucial to developing conservation management strategies.

Herein, our main goal was to analyze bat communities in two areas of the Afromontane forest biome of Cameroon (undisturbed area and disturbed areas) to assess bat response to habitat degradation. Our objective was to compare species richness and abundance between these two habitat types. Studies that compare bat communities in pristine forests and humandisturbed forests in similar life zones can provide insight into the original bat communities of an area and the effect that deforestation and fragmentation have on bat communities. Such studies are important to determine the extent of human influence in the spatial and temporal variations of biodiversity in an 
ecosystem. This information can also throw more light on the habitat preferences of some bat species and hence understand the potential risk of local extinction and community homogenization (Henle et al., 2004; Myers et al., 2015). Furthermore, comparing bat communities across different habitats can enable researchers to assess the health of an ecosystem given that bats are suitable indicator species that show sensitivity to human induce disturbances (Medellín et al., 2002; Jones et al., 2009; Meyer et al., 2016). We expect species richness, relative abundance, and the number of forest specialist species to be higher in undisturbed areas than in disturbed areas.

\section{MATERIALS AND METHODS}

\section{Study Sites}

We carried out this study on Mount Cameroon, Mount Manengouba, and Mount Bamboutos (Figure 1). These mountains are part of the Afromontane forest biome of Cameroon that encompasses other mountains of the Cameroon Highlands.

Undisturbed habitats were located within the Mount Cameroon National Park $\left(4^{\circ} 9^{\prime} 36.5^{\prime \prime} \mathrm{N}, 9^{\circ} 16^{\prime} 44.9^{\prime \prime}\right.$ E). Mount Cameroon National Park (MCNP) covers an area of 58.178 ha. The climate is maritime and equatorial, characterized by two seasons: a short dry season between December and February and a longer rainy season between March and November (Payton, 1993). The annual temperature fluctuates between $4^{\circ} \mathrm{C}$ at the summit and $32^{\circ} \mathrm{C}$ at the coast and decreases by $0.45^{\circ} \mathrm{C}$ with every $100 \mathrm{~m}$ rise in elevation (Payton, 1993). The annual rainfall averages 7,000 mm, with most of the rain occurring in July and October (Forboseh et al., 2011). Rainfall decreases with elevation from approximately $4,000 \mathrm{~mm}$ at $1,000 \mathrm{~m}$ to less than $3,000 \mathrm{~mm}$ above 2,000 $\mathrm{m}$ (Payton, 1993). The area is characterized by a pristine forest of large and tall trees forming a continuous close canopy except in areas where the vegetation is disturbed by forest elephants. The flora composition in all 10 undisturbed habitat sites is similar. The tree species frequently encountered include African cherry (Prunus africana), brittle-wood (Nuxia congesta), African nutmeg (Pycnanthus angolensis), African teak (Milicia excelsa), umbrella tree (Musanga cecropioides), the monkey fruit (Myrianthus arboreus), with associated spiny tree ferns (Cyathea manniana and Cyathea camerooniana), and tall herbaceous plants such as Aframomum spp. (Letouzey, 1985).

Disturbed habitat sites surveyed were located at the southeast slope of Mount Manengouba at the littoral side of the mountain and the foothill of Mount Bamboutos. The Manengouba Mountain $\left(5^{\circ} 1^{\prime} 48^{\prime \prime} \mathrm{N}, 9^{\circ} 49^{\prime} 48^{\prime \prime} \mathrm{E}\right)$ is an extinct volcano that peaks at $2,411 \mathrm{~m}$. The caldera harbors two volcanic lakes with the largest being $600 \mathrm{~m}$ across. Mount Manengouba has an equatorial climate, with an annual rainfall and temperature means of $2,316 \mathrm{~mm}$ and $20.3^{\circ} \mathrm{C}$, respectively. The relative humidity is $84 \%$ (Enang et al., 2019). The Montane forest of Mount Manengouba is described as dry, stunted and patchy, and disturbed from farming, tree-cutting, burning, and grazing (Collar and Stuart, 1988). The peak and southern and southeastern slopes are forested.
The survey sites at lower elevations $(<1,200 \mathrm{~m})$ are characterized by human settlements and agricultural areas composed of small farmlands on which crops such as corn (Zea mays), beans (Phaseolus vulgaris), cocoyam (Colocasia esculenta), yams (Dioscorea cayenensis), and plantains (Musa paradisiaca) were cultivated. There were also backyard orchards near houses with fruiting trees such as mango (Mangifera indica), avocado (Persea americana), guava (Psidium guajava), plums (Dacryodes edulis), and oil palm (Elaeis guineensis) plantations. At higher elevation sites $(>1,200 \mathrm{~m})$ the forest was still intact with riparian forest vegetation surrounding small rivers which remain largely undisturbed. The herbaceous vegetation at these higher elevation sites is reduced because of intense grazing by cattle and sheep of Fulani communities living near the summit of the mountain.

Mount Bamboutos $\left(5^{\circ} 40^{\prime} 0.1^{\prime \prime} \mathrm{N}, 10^{\circ} 3^{\prime} 0^{\prime \prime} \mathrm{E}\right)$ is the third tallest mountain of the Cameroon Volcanic Line after Mount Cameroon and Oku (Gountié Dedzo et al., 2011). A dry season that extends from November to March and a wet one from April to October characterize the climate of Mount Bamboutos. The average annual rainfall is $1,918 \mathrm{~mm}$ and the average temperature is $18.9^{\circ} \mathrm{C}$ at an elevation of $2,700 \mathrm{~m}$ (Kengni et al., 2009). Crop fields and eucalyptus plantations characterized the two sites sampled on the Bamboutos Mountain.

\section{Bat Sampling Protocol}

Bat surveys employing standard mist-netting techniques were conducted in the disturbed habitats of Manengouba and Bamboutos mountains during non-consecutive nights between 13 June to 27 August 2019 in the rainy season and 28 October to 9 December 2019 in the dry season. Surveys in the undisturbed habitats between 11 January 2019 and 24 March 2020 in the dry season. Within each habitat type (undisturbed and disturbed forest). Sampling sites were chosen based mainly on the accessibility, and quality of sites for capturing bats with high-quality sites such as across or along the banks of slowflowing streams, orchards, forest understory, and gaps between trees chosen for placement of mist nets. The coordinates of each sampling station were recorded using a GPS (Garmin eTrex 10). In total sampling was conducted for 68 nights, comprising of 34 nights in each habitat type. Six mist nets of various lengths (four $12 \mathrm{~m} \times 2.5 \mathrm{~m}$ and two $6 \mathrm{~m} \times 2.5 \mathrm{~m}$ Ecotone, Poland), all with four shelves, and a mesh diameter of $30 \mathrm{~mm}$ were deployed at each site per sampling night. The nets were kept open from about 6:00 pm to midnight in each sampling night until bat activity had reduced drastically. Mist-nets were closed earlier whenever weather conditions worsened. Sampling was only conducted during windless, rainless, and moonless nights to maximize the chances of capturing many individuals (Morrison, 1978). When capture was carried out on consecutive nights, the placement and configuration of mist nets were changed in an attempt to prevent the recapture of bats. We checked the nets every $15 \mathrm{~min}$. Manipulation of all bats captured followed the guidelines of the American Society of Mammalogists (Sikes and The Animal Care and Use Committee of the American Society of Mammalogists, 2016). Each bat captured was identified to species, sexed, weighed using a calibrated digital scale $(500 \mathrm{~g} \times 0.1 \mathrm{~g}$, Ohaus), and morphometric measurements were taken using a dial caliper 


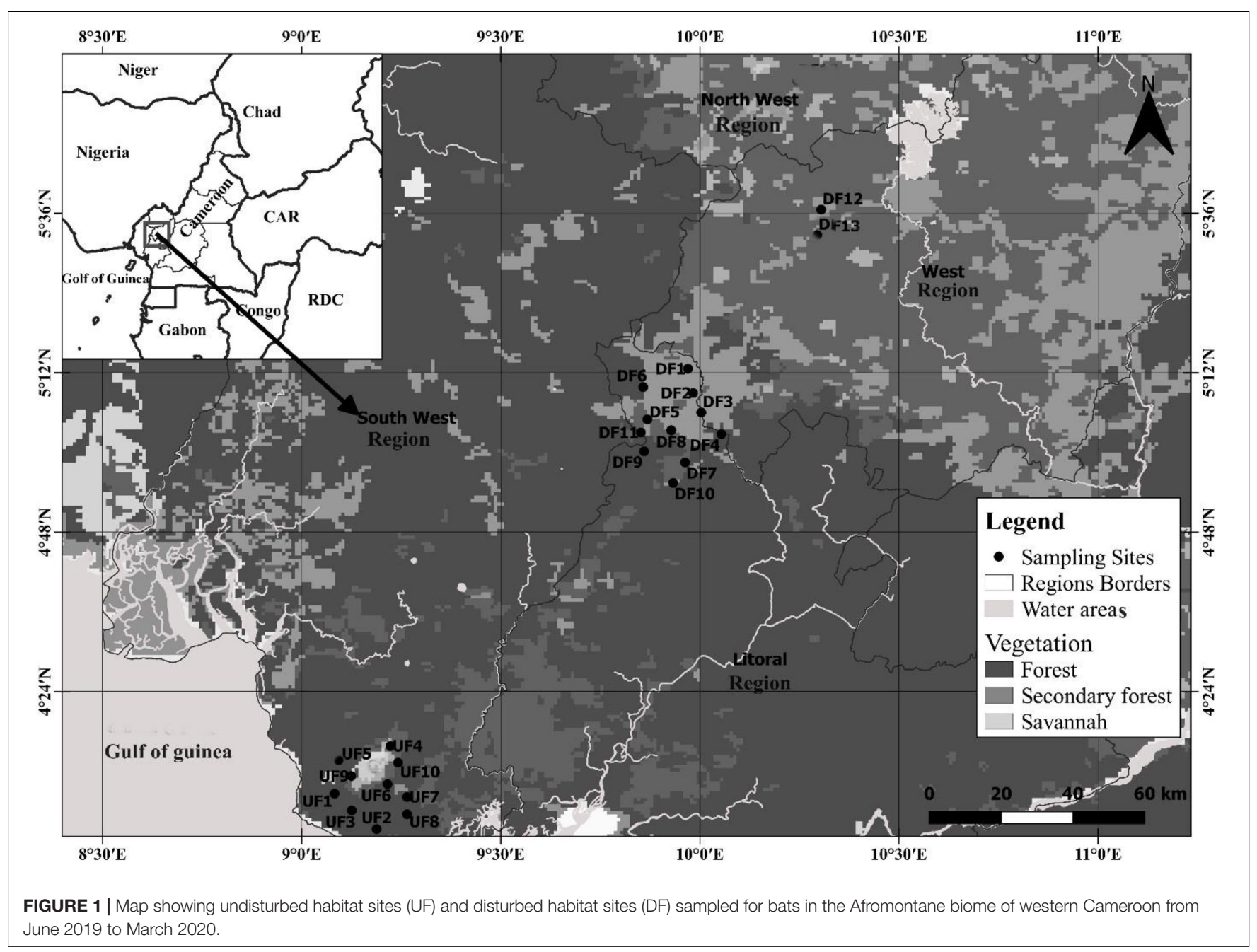

(Ecotone-Poland 150/0.1 mm). Age was determined by the degree of ossification of the carpal joints of the wing, conditions of the pelage, and the development of nipples and testes (Baagøe, 1977; Anthony, 1988). Each captured bat was then released near the point of capture except for a male and female representative of each species that were euthanized and kept as vouchers deposited at the Laboratory of Zoology of the University of Maroua. Field identification of bats was based on the keys provided by Patterson and Webala (2012) and species accounts provided by Monadjem et al. (2010) and Happold and Happold (2013). Taxonomic nomenclature for pipistrelle-like bats follows Monadjem et al. (2021). Species that could not be identified in the field and rare species were euthanized and stored in $70 \%$ ethyl alcohol for later identification using craniodental characteristics (Bates et al., 2005). Bat species were also grouped into different foraging guilds according to Schnitzler and Kalko (2001) and Denzinger and Schnitzler (2013).

\section{Statistical Analyses}

Expected species richness was computed for both the undisturbed and disturbed forests using an individual-based non-parametric species estimator because our main goal was to estimate the total number of species of a particular habitat type rather than species density (number of species per unit area). The species richness estimator Jackknife 1 was employed to estimate species richness because of its low-bias estimation and high precision even at a small sample size (Colwell and Coddington, 1994). Jackknife 1 also considers the movement heterogeneity of highly mobile animals such as bats (Brose and Martinez, 2004). All analyses were performed in EstimateS 9.1.0 software (Colwell, 2013) involving 1,000 randomizations. We assessed the completeness of the bat surveys in the two habitat types by calculating the percentage of estimated species richness that was effectively covered by our sampling. The percentage of inventory completeness was calculated as Sobs/Sest multiplied by 100 where Sobs is the number of species observed, and Sest is the number of species estimated (Estrada-Villegas et al., 2010).

Sampling effort (net hours) was obtained by multiplying the area of a mist net by the number of nets each night and the total number of hours (Straube and Bianconi, 2002). We calculated the capture success by dividing the number of bats captured at each sampling site by the sampling effort. Species accumulation curves were used to estimate species richness based on the accumulated number of species observed, compare species richness among 
habitats, and measure sampling completeness (Magurran, 2004). Effects of human disturbance were measured as differences in species richness, species composition, and abundance between undisturbed and disturbed habitats.

Bat diversity in both habitat types was described based on two ecological indices of Simpson's index (Simpson, 1949) and the Evenness or Equitability index (Pielou, 1969). We computed the Simpson's index (D), which gives the probability of any two individuals randomly drawn from a community belonging to different species. The Simpson's index provides a good estimate of diversity even for small sample sizes (Magurran, 2004). It was computed using the formula $(D)=1-\left[\sum \mathrm{n}(\mathrm{n}-1) / \mathrm{N}(\mathrm{N}-1)\right]$, where $n=$ the total number of bats of a particular species, $N=$ the total number of bats of all species. The value of $D$ ranges between 0 and 1 , where 0 represents complete uniformity 1 represents complete diversity (Simpson, 1949). We derived the Evenness index $\left(J^{\prime}\right)$, which indicates how abundances are distributed among species in the community, from the Shannon index of diversity ( $\left.\mathrm{H}^{\prime}\right)$. Evenness or Equitability index was computed using the formula $\left(J^{\prime}\right)=\mathrm{H}^{\prime} /$ In $S$, where In $\mathrm{S}=$ natural logarithm of the number of species or species richness. The Evenness index ranges from 0 (one dominant species) to 1 (all species equally abundant in the community). When the evenness index is high, it indicates that species are equally abundant while lower evenness index values indicate that species are not equally abundant (Magurran, 1988).

We performed the independent samples $t$-tests to investigate if there was a variation in observed bat species richness, relative abundance, bat diversity (for the Simpson index), and evenness between the undisturbed and disturbed forest habitats. The data were tested for normality using Kolmogorov-Smirnov's test, and for homogeneity of variance using Levene's test before performing the $t$-test. We performed the Mann-Whitney $U$ test when the condition of normality and homogeneity of variance was not met. Box plots were used to show the relationship between species richness, abundance, evenness, and diversity between undisturbed and disturbed forest habitats.

We used non-metric multidimensional scaling (NMDS) as a non-linear ordination technique based on Bray-Curtis similarity to ordinate all 23 sampled sites to assess and visualize intersite similarity in species composition. The NMDS uses rank orders to evaluate dissimilarities between different communities instead of absolute distances, with "stress" being a measure of the distortion (final lack of agreement) (McCune and Grace, 2002). Data were square-root transformed before analysis to down-weight most abundant species relative to rare ones (i.e., the transformation reduces the magnitude of the larger number relative to the smaller ones without changing the relationship). One-way analysis of similarity (ANOSIM) with a Jaccard distance matrix was used to assess differences in bat species composition between forest habitat types (Clarke, 1993). The $R$-value was used to determine the similarity between the two forest habitat types. The values range from 0 to 1 , with values closer to 1 indicating higher dissimilarity between a pair of sampling sites being compared, and values closer to 0 indicating greater similarity (Clarke, 1993). Finally, we carried out a similarity percentage analysis (SIMPER) to determine the contribution of each species to the overall similarity of bat communities between undisturbed and disturbed habitat-type. All multivariate analyses were conducted using PAST software (Hammer et al., 2001). Mantel test was employed to test the prediction that greater homogeneity of undisturbed sites was based on spatial proximity rather than the lack of disturbance. Mantel test analysis was performed using the vegan package in R software version 4.1.1 (Oksanen et al., 2018).

\section{RESULTS}

\section{Effects of Anthropic Disturbances on Bat Communities}

A total of 477 bats representing 21 species, 15 genera, and five families were recorded in both forest habitat types surveyed (Table 1). The overall species richness we recorded was greater in the disturbed habitats (16 species) than in the undisturbed habitats (13 species; Figure 2). However, the difference was not statistically significant [ $t$-test; $t(21)=-1.052, P=0.305]$. The estimated Jackknife 1 species richness amounted to 27.69 for the entire area sampled (Figure 3). Therefore, our surveys sampled $75.84 \%$ of all richness estimated for the study area. The estimated species richness for the disturbed habitats was 21.53 and that for the undisturbed habitat was 19.30 species (Figure 3 ). In addition, more individuals were recorded in the undisturbed habitats $51.15 \%(n=244)$, than in the disturbed habitats $48.85 \%(n=233)$. The difference in population size between the two forest types sampled was not statistically significant [ $t$-test; $t(21)=0.595$, $P=0.356]$.

Among species recorded, five (23.81\%) were recorded exclusively in the undisturbed habitat. These species were Scotonycteris zenkeri, Doryrhina cyclops, Hipposideros cf. ruber, Glauconycteris egeria, and Glauconycteris sp. On the other hand, seven species $(33.33 \%)$ captured in the disturbed habitat were absent in the undisturbed habitat. These species were Eidolon helvum, Epomops franqueti, Micropteropus pusillus, Rhinolophus fumigatus, Hipposideros cf. caffer, Glauconycteris argentata, and Laephotis inexpectatus. Eight species (38.09\%) were common to both habitat types. These species were Megaloglossus woermanni, Myonycteris angolensis, Rousettus aegyptiacus, Rhinolophus landeri, Macronycteris gigas, Miniopterus sp., Afronycteris nana, and Pipistrellus nanulus. Myonycteris angolensis, Rhinolophus landeri, and Afronycteris nana were the only species captured in equal proportion in both forest types.

Five families were recorded during our surveys. Pteropodidae was the most abundant, with $78.69 \%$ of all captures, followed by Hipposideridae with $7.76 \%$, Vespertilionidae with $6.29 \%$, and Miniopteridae with $6.08 \%$. When taking into account the whole area sampled, the most abundant species were Rousettus aegyptiacus $27.85 \%$, followed by Myonycteris angolensis, $23.21 \%$. The most abundant species in the undisturbed forest was Rousettus aegyptiacus 25.3\%, followed by Myonycteris angolensis with $11.5 \%$, while in the disturbed forest habitats Micropteropus pusillus was the most abundant with 10.9\%, followed by Myonycteris angolensis $10.7 \%$ (Figure 4). Few individuals of Rousettus aegyptiacus were recorded in the disturbed forest than in the undisturbed forest (Table 1). 
TABLE 1 | Number of individuals, species richness, functional guild, sampling effort, capture success and relative abundances in parentheses of bats captured in undisturbed and disturbed habitat sites of the Afromontane forest biome of western Cameroon from June 2019 to March 2020.

\begin{tabular}{|c|c|c|c|c|}
\hline Taxon & Undisturbed habitat & Disturbed habitat & Functional guild & Total \\
\hline \multicolumn{5}{|l|}{ Family Pteropodidae } \\
\hline Eidolon helvum (Kerr, 1792) & - & $22(4.6)$ & frugivore & $22(4.6)$ \\
\hline Epomops franqueti (Tomes, 1860) & - & $19(4.0)$ & frugivore & $19(4.0)$ \\
\hline Megaloglossus woermanni (Pagenstecher, 1885) & $12(2.5)$ & $1(0.2)$ & nectarivore & $13(2.7)$ \\
\hline Micropteropus pusillus (Peters, 1868) & - & $52(10.9)$ & frugivore & $52(10.9)$ \\
\hline Myonycteris angolensis (Bocage, 1898) & $55(11.6)$ & $51(10.7)$ & frugivore & $106(22.3)$ \\
\hline Myonycteris torquata (Dobson, 1878) & - & $25(5.3)$ & frugivore & $25(5.3)$ \\
\hline Rousettus aegyptiacus (E. Geoffroy, 1810) & $120(25.2)$ & $12(2.5)$ & frugivore & $132(27.7)$ \\
\hline Scotonycteris zenkeri (Matschie, 1894) & $4(0.8)$ & - & frugivore & $4(0.8)$ \\
\hline \multicolumn{5}{|l|}{ Family Rhinolophidae } \\
\hline Rhinolophus fumigatus (Ruppell, 1842) & - & $4(0.8)$ & closed space & $4(0.8)$ \\
\hline Rhinolophus landeri (Martin, 1838) & $2(0.4)$ & $2(0.4)$ & closed space & $4(0.8)$ \\
\hline \multicolumn{5}{|l|}{ Family Hipposideridae } \\
\hline Doryrhina cyclops (Temminck, 1853) & $1(0.2)$ & - & closed space & $1(0.2)$ \\
\hline Hipposideros cf. caffer (Sundevall, 1846) & - & $1(0.2)$ & closed space & $1(0.2)$ \\
\hline Hipposideros cf. ruber (Noack, 1893) & $32(6.7)$ & - & closed space & $32(6.7)$ \\
\hline Macronycteris gigas (Wagner, 1845) & $1(0.2)$ & $2(0.4)$ & closed space & $3(0.6)$ \\
\hline \multicolumn{5}{|l|}{ Family Miniopteridae } \\
\hline Miniopterus sp. & $4(0.8)$ & $25(5.3)$ & edge space & $29(6.1)$ \\
\hline \multicolumn{5}{|l|}{ Family Vespertilionidae } \\
\hline Afronycteris nana (Peters, 1852) & $1(0.2)$ & $1(0.2)$ & edge space & $2(0.4)$ \\
\hline Glauconycteris argentata (Dobson, 1875) & - & $13(2.7)$ & edge space & $13(2.7)$ \\
\hline Glauconycteris egeria (Thomas, 1913) & $1(0.2)$ & - & closed space & $1(0.2)$ \\
\hline Glauconycteris sp. & $1(0.2)$ & - & closed space & $1(0.2)$ \\
\hline Laephotis inexpectatus (Aellen, 1959) & - & $1(0.2)$ & edge space & $1(0.2)$ \\
\hline Pipistrellus nanulus (Thomas, 1904) & $10(2.1)$ & $2(0.4)$ & edge space & $12(2.5)$ \\
\hline Total & $244(51.2)$ & $233(48.8)$ & & $477(100)$ \\
\hline Species richness & 13 & 16 & & \\
\hline Sampling effort $\left(\mathrm{m}^{2} / \mathrm{h}\right)$ & 29520 & 28543 & & \\
\hline Capture success (Individuals $/ \mathrm{m}^{2} \mathrm{~h}$ ) & 0.007 & 0.006 & & \\
\hline Shannon index $\left(\mathrm{H}^{\prime}\right)$ & 1.52 & 2.1 & & \\
\hline Simpson's index (D) & 0.67 & 0.85 & & \\
\hline Equitability index (J) & 0.59 & 0.77 & & \\
\hline
\end{tabular}

There was a higher diversity $D$ (Simpson's index) of bats in disturbed forest $(D=0.85)$ than undisturbed forest $[D=0.67$; $t(21)=3.460, P=0.002]$, but no statistically significant difference in equitability for the bats captured in the disturbed habitat $\left(J^{\prime}=0.77\right)$ and undisturbed forests $\left(J^{\prime}=0.59\right.$; Mann-Whitney $U$ test; $U=38, P=0.181$ ).

The NMDS ordination analysis showed that most of the undisturbed forest sites are more closely grouped therefore are more similar in terms of bat composition compared to disturbed forest sites (Figure 5). Analysis of Similarity (ANOSIM) indicated that there was a statistically significant difference in the overall bat community of the two forest types $(R=0.321, P=0.0001)$. The stress value $(0.23)$ indicated that this ordination is a good representation of the bat community structure. Similarity Percentages Analysis (SIMPER) identified four species that contributed the most to the difference in the composition of bat species between undisturbed forest habitats and disturbed forest habitats: Rousettus aegyptiacus, Myonycteris angolensis,
Hipposideros cf. ruber, and Micropteropus pusillus (Figure 6). Using the Bray-Curtis index, the dissimilarity of bat communities in undisturbed forest sites significantly increased with geographic distance (Mantel $r=0.99, p=0.001$ ) suggesting that sites with closer spatial proximity have more similar bat compositions.

\section{Composition of Bat Guilds in Undisturbed and Disturbed Forest Habitats}

We recorded three different functional guilds during our surveys, namely frugivorous bats, closed-space forager insectivorous bats, and edge-space forager insectivorous bats (Figure 7).

In terms of the number of species, closed-space forager insectivorous bats were the largest guild in the undisturbed habitat with six species, while frugivorous bats were the largest guild in the disturbed habitat with seven species (Figure 7A). A comparison between both habitat types showed that there was 

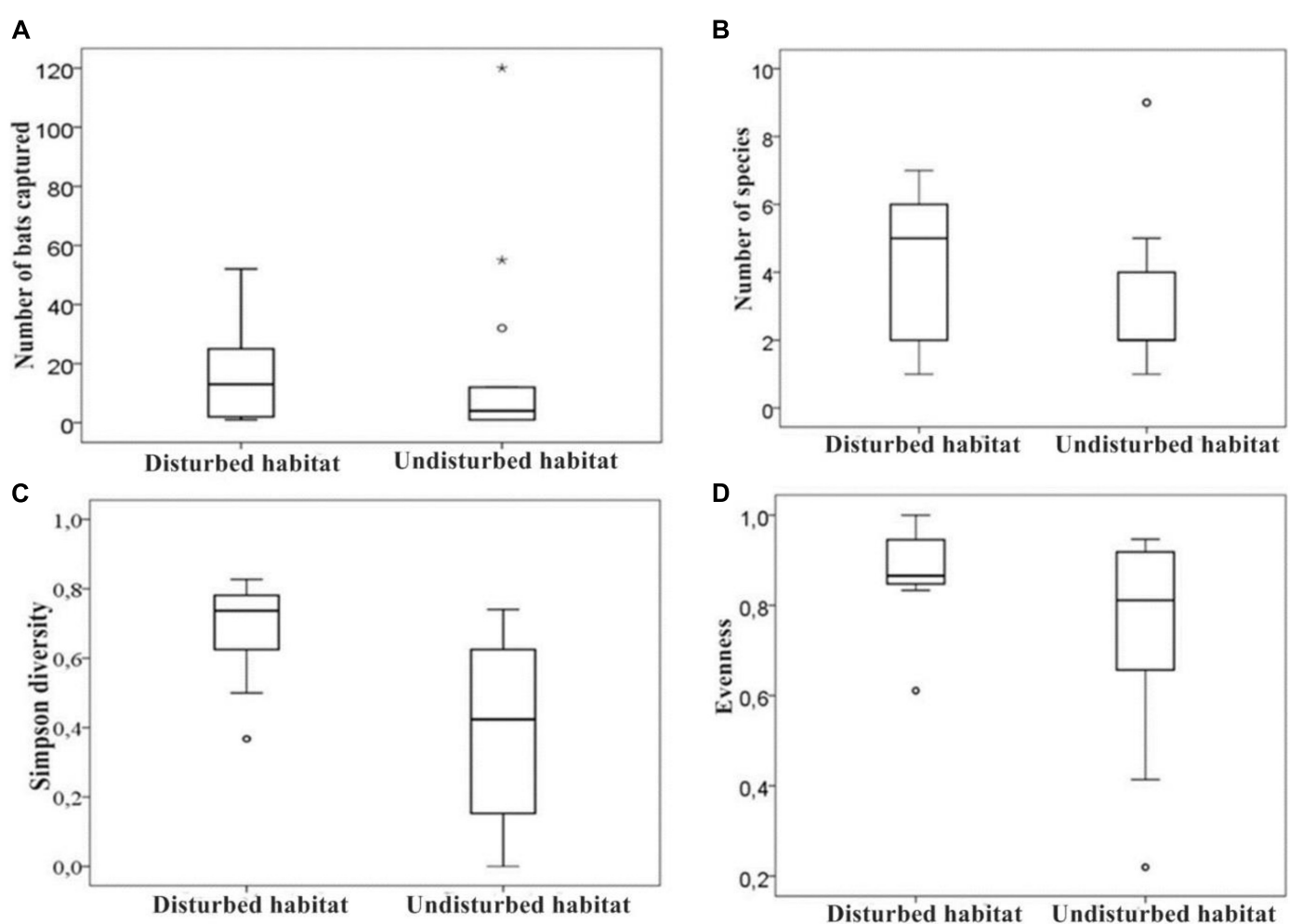

FIGURE 2 | Box plots comparing variation in abundance (A), species richness (B), Simpson diversity (C), and habitat evenness (D) of bats in undisturbed and disturbed habitat sites of the Afromontane biome of western Cameroon. The small circles (o) and asterisks $\left(^{\star}\right)$ represents outliers and extreme outliers respectively.

a statistically significant difference in the number of species of frugivorous bats [ $t$-test; $t(21)=-2.785, P=0.011$; Figure 7A]. However, the relative abundance of frugivorous bat species among forest types did not differ significantly $[t(14)=-4.92$, $P=0.628$; Figure 7B]. Additionally, there was no evidence of a significant difference in the number of forest specialist insectivorous bats between disturbed and undisturbed forests (Mann-Whitney $U$ test; $U=44.5, P=0.208$ ). Similarly, there was no significant difference in the relative abundance of

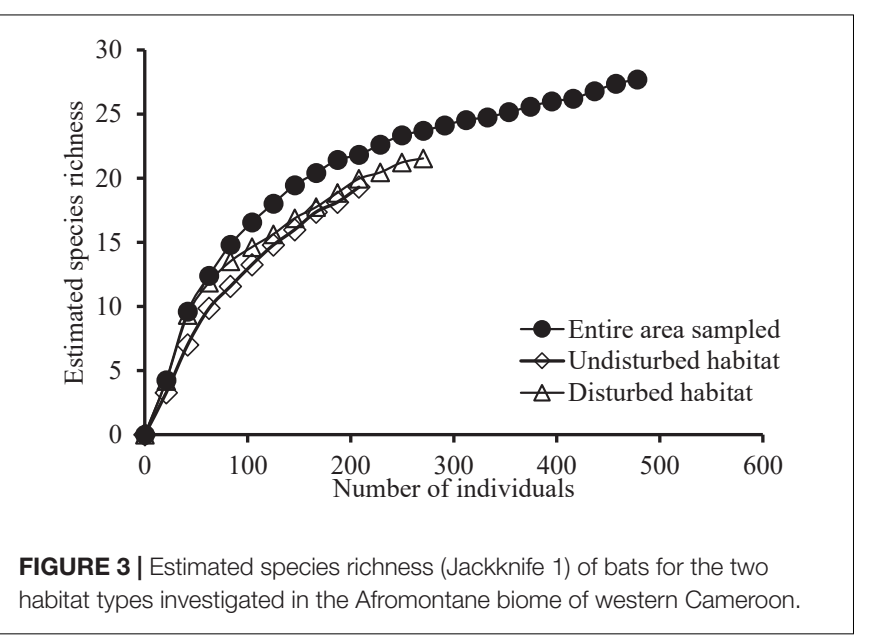

closed-space insectivorous bats between the two forest types (Mann-Whitney $U$ test; $U=49.5, P=0.343$ ). Edge-space insectivorous bats were not considered because of few captures to enable accurate comparison.

\section{DISCUSSION}

In this study, we surveyed bats in pristine and disturbed vegetations of the Afromontane biome of western Cameroon. Our study revealed that the disturbed forest supported larger populations and more species than the undisturbed forest sites, although the species richness did not differ significantly between the two forest types. There was a significant change in bat composition from mostly widespread generalists in the disturbed forest, to forest species in the undisturbed forest. This difference in species richness and abundance could likely be explained by greater habitat heterogeneity of the disturbed forests (Estrada and Coates-Estrada, 2002; Ramos Pereira et al., 2009). Indeed, the disturbed forests were more heterogeneous comprising of areas with secondary forest patches, gallery forests, coffee plantations, palm plantations, orchards, and cultivated farmlands. On the other hand, the undisturbed forest was characterized by primary growth with large trees, continuous canopy, dense understory, and a patchier understory cover at the ecotone montane forest/montane grassland. Both forest types were located in a volcanic landscape with numerous extinct 


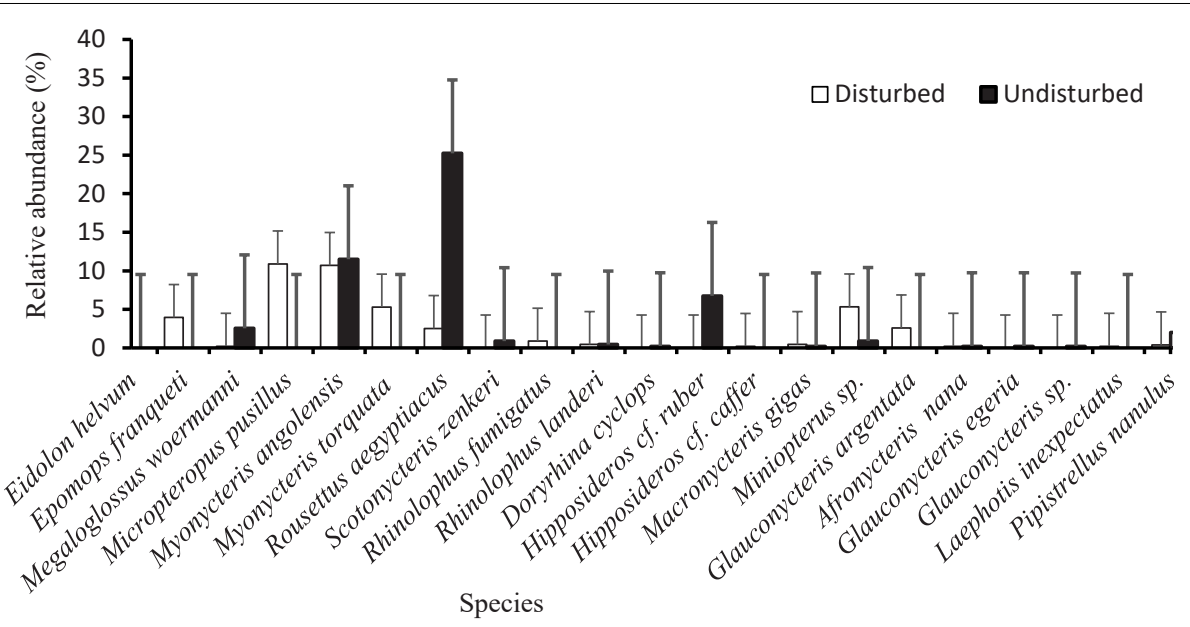

FIGURE 4 | Relative abundance of 21 bat species captured in undisturbed and disturbed habitat sites of the Afromontane forest biome of western Cameroon. Bars indicate standard error.

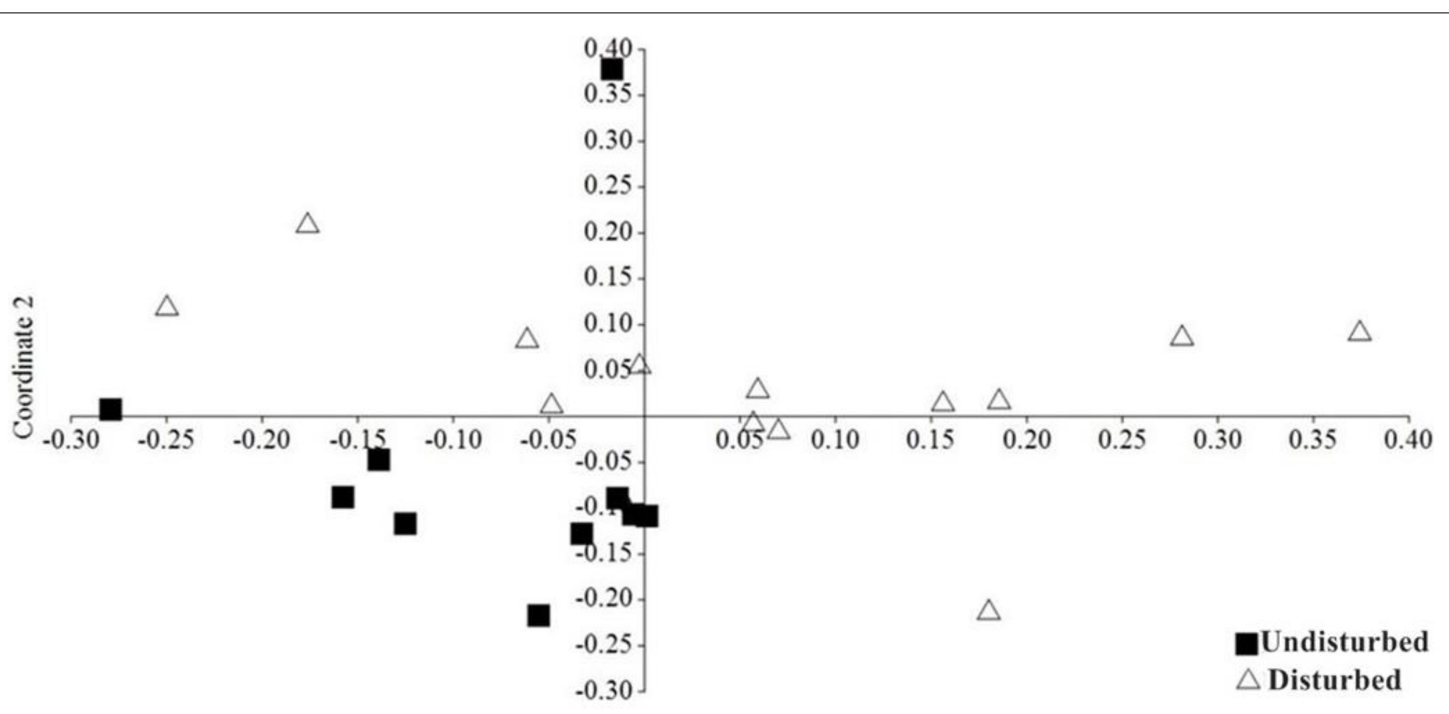

Coordinate 1

FIGURE 5 | NMDS ordination, showing the difference between undisturbed and disturbed habitat sites of the Afromontane biome of western, Cameroon based on the composition and abundance of bat species using the Bray-Curtis index as a measure of similarity (Stress $=0.23$ ).

volcanic vents that probably provided day roosts for obligate cave roosters (Glover and Altringham, 2008).

Habitat structural heterogeneity is associated with an increase in bat species activity and species occurrence (Jung et al., 2012). The heterogeneous landscape offered more resource opportunities for open-adapted species in these modified habitats, due to their ability to access extra resources such as artificial shelters and food resources (Loeb et al., 2009; Coleman and Barclay, 2012). Indeed, bats are specially adapted to access a wide diversity of habitats, occupying many ecosystems (Schnitzler and Kalko, 2001). An alternative explanation is the presence of more open water bodies in the disturbed areas which provided drinking and foraging sites for bats (Grindal et al., 1999; Campbell, 2009), leading to increased bat activity and their subsequent capture in mist-nets. The species accumulation curves did not show a tendency toward plateauing, suggesting that our surveys did not capture all species present in the study area. However, $75.84 \%$ of the estimated species richness was sampled, indicating that more species will be recorded with a greater sampling effort.

Our findings concur with other studies that demonstrated the positive effects of human disturbances on species richness and abundance of species adapted to forage in open areas, but that fragmentation negatively affects bat species that depend on pristine habitats (Klingbeil and Willig, 2009; Estrada-Villegas et al., 2010). Greater species richness and abundance in the disturbed forest can also be attributed to the greater amount of forest edge in the disturbed habitats. 


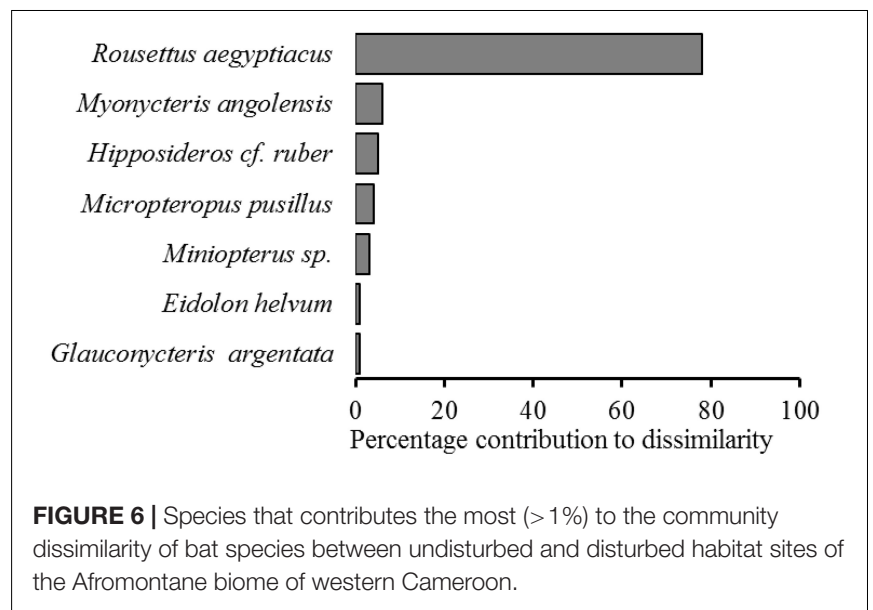

According to Fried et al. (2005), edge habitats contain more flying insects, hence attracting more foraging insectivorous bats, and subsequently allowing some to be captured in mist-nets. Hence a possible consequence of the continuous deforestation and fragmentation will be the replacement of forest-interior species by more adaptable and opportunistic forest edge frugivorous bats such as Eidolon helvum, Micropteropus pusillus, Myonycteris angolensis, and edge tolerant insectivorous bats such as Glauconycteris argentata (Webala et al., 2019). Understory frugivorous bats such as Scotonycteris zenkeri and Megaloglossus woermanni are also sensitive to fragmentation, and thus will be negatively impacted by deforestation than larger canopy foragers (Cosson et al., 1999). On the other hand, our findings contrast, some studies in the Neotropics by Gorresen and Willig (2004) in Paraguay, which concluded that bat community diversity was highest in relatively undisturbed forests, and findings by Estrada and Coastes-Estrada (2001) which concluded that bats within the continuous forest and forest fragments in Mexico had similar species richness.

Guild structure differs between the two forest habitat types, probably indicating the uneven distribution of resources. According to Hodgkison et al. (2004), the abundance of bats is influenced by the temporal and spatial variation of food resources, which then influence the number of species within a particular habitat (Duchamp et al., 2007; Pinto and Keitt, 2008). While the number of frugivorous bats did not differ significantly between the habitat types, there was a higher proportion of frugivorous bat species in the disturbed habitat than in the undisturbed habitat. This can probably be explained by the presence of many forest tree species such as Ficus spp., Prunus africana, Annona senegalensis, Borassus aethiopum, Hymenocardia acida, Nauclea diderrichii, Musanga cecropioides, and Caloncoba welwitschii, among species of fruiting trees planted by humans such as Persea americana, Carica papaya, Anonidium mannii, and Dacryodes edulis. The presence of more closed-spaced forager insectivorous bat species in the undisturbed habitat can probably be attributed to the nature of their echolocation calls. These species use low-intensity, high-frequency echolocation calls, characterized by low wing

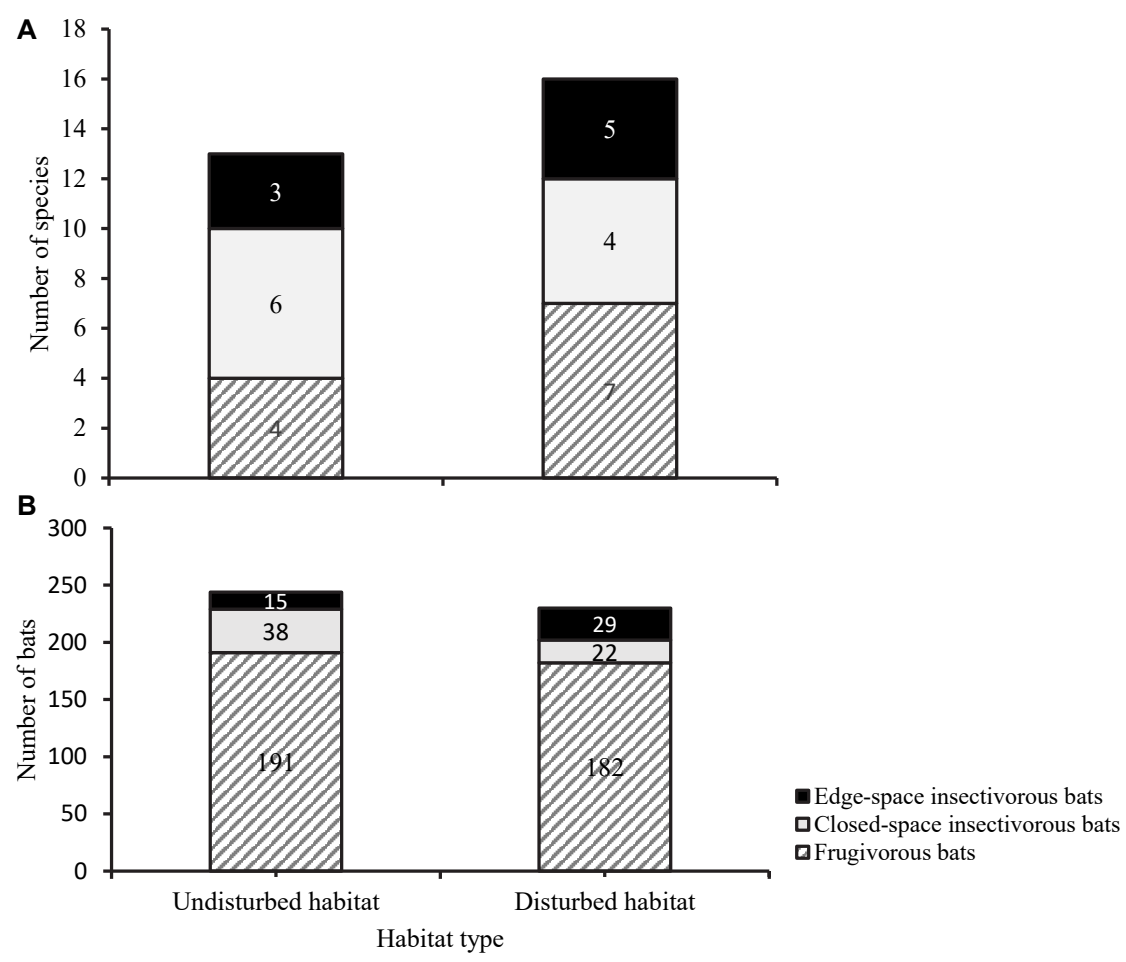

FIGURE 7 | Proportion of functional guild among bat species in undisturbed and disturbed habitat sites of the Afromontane forest biome of western Cameroon, considering species richness (A) and abundance (B). 
loadings, appropriate for foraging and commuting in cluttered habitats close to vegetation (Law et al., 2011). Therefore, the increase in anthropogenic disturbances can significantly reduce the resource availability for these species (Threlfall et al., 2012). This is consistent with findings by Webala et al. (2019) who captured more closed-space insectivorous bat species in the less-disturbed forest interior with little human disturbance in a Kenyan forest. In addition, the capture of more edge-space insectivorous bat species in the disturbed forest can be attributed to their flexible commuting traits, which enabled them to adapt to cleared environments, including agricultural areas and residential spaces. Thus, these open-adapted species are relatively insensitive to human modification, and in many cases, can exploit manmade structures (Kirsten and Klomp, 1998; Threlfall et al., 2012). Indeed, the fact that some close-space forager insectivorous bat species persist in human-dominated environments is an indication of the versatility and adaptability of some bat species.

In our surveys family, Pteropodidae represented the largest number of captures. This pattern can be attributed both to the high abundance of pteropodid bats in the surveyed area and the use of ground-level mist-netting method, which tends to be more effective at capturing low-foraging frugivorous bats (Meyer et al., 2011). Moreover, it is well documented that fast-flying insectivorous bat species that forage higher at the middle-story and canopy levels, above the height of mist-nets, and adept at detecting and avoiding mist-net due to their very efficient echolocation calls are undersampled in ground-level mist-net surveys, resulting in underestimates of the actual species richness and abundance (Kalko and Handley, 2001; Kalko et al., 2008). This probably explains the absence of molossids, emballonurids, nycterids, and the capture of only a few vespertilionids during our surveys. It is, therefore, imperative to employ different sampling methods such as sub-canopy and canopy nets, acoustic detectors, and harp traps to complement ground-level mist nets for the detection of species that are considered rare or difficult to capture (Kunz and Parsons, 2009; Estrada-Villegas et al., 2010; Fahr and Kalko, 2010) and to obtain more complete inventories of bats (Bergallo et al., 2003; MacSwiney et al., 2008; Furey et al., 2009; Meyer et al., 2011; Silva and Bernard, 2017).

While the majority of bat species were captured in only one habitat type, some species were captured in both the pristine and disturbed habitats, e.g., Megaloglossus woermanni, Myonycteris angolensis, Rousettus aegyptiacus, Rhinolophus landeri, Macronycteris gigas, Miniopterus sp., Afronycteris nana, and Pipistrellus nanulus. The fact that these species were captured in both habitat types suggested that they are probably generalist species that can tolerate and forage in modified habitats. These species can therefore access additional resources outside of remnant forest patches, such as artificial shelters and food resources (Gehrt and Chelsvig, 2003; Duchamp and Swihart, 2008; Loeb et al., 2009; Coleman and Barclay, 2012).

Megaloglossus woermanni was mostly recorded in the undisturbed (primary) forest during our surveys. However, a single individual was recorded over a stream at a high elevation site on Mt. Manengouba. This nectarivorous bat is common in closed forests but may enter cultivated areas adjacent to the forest to feed on flowers. It is common in areas where flowers persist throughout the year. This species has also been recorded in disturbed areas in the Center Region of Cameroon (Waghiiwimbom et al., 2019), as well as in relatively undisturbed forest in the Mpem and Djim National Park by Atagana et al. (2018) and in the Dja biosphere reserve by Bakwo Fils (2009). The fact that this species has been recorded in both habitat types is an indication that it might benefit when natural areas are converted to agricultural landscapes. For example, Weber et al. (2009) captured this species, while it fed on flowers of cultivated bananas around a forested area in Benin.

Rousettus aegyptiacus and Myonycteris angolensis are large cavernicolous frugivorous bat species that were recorded in both pristine and disturbed habitats. The distribution of these species is largely dependent on the availability of suitable caves as day roost (Weber and Fahr, 2006; Monadjem et al., 2010). These species are known to have a broad habitat tolerance and probably have generalist-feeding habits. The capture of these species at disturbed habitats suggests that they are relatively tolerant to habitat fragmentation and may take advantage of the seasonal fluctuation in fruit production by fruiting trees such fig (Ficus sp.), apricot (Prunus sp.), peach (Prunus sp.), mango (Mangifera indica) mostly present in disturbed areas. These species have also been recorded in disturbed areas in Cameroon (Mongombe et al., 2019; Waghiiwimbom et al., 2019; Manfothang et al., 2020, 2021), and undisturbed areas (Bakwo Fils, 2009; Atagana et al., 2018).

The presence of Macronycteris gigas in undisturbed forest patches is not that surprising given that this species forages around the edges of clutter, where it often intercepts large flying insects from a foraging perch (Vaughan, 1977). Monadjem et al. (2016) also recorded this species in forested and disturbed habitats in the Guinean Mount Nimba. The presence of Rhinolophus landeri, Afronycteris nana, and Pipistrellus nanulus in both habitat types was not that surprising because these species are associated with primary and secondary forest habitats (Monadjem et al., 2010).

\section{Conservation and Management Implications}

Our surveys suggest that forest loss has strong ramifications on bat species richness and functional richness. In addition, different guilds respond differently to different habitat attributes. These results reveal that disturbed habitats with forest patches are important for the conservation of bat species. Especially those that are adaptable and less sensitive to habitat disturbance, preferring fragmented landscape for commuting and foraging. Therefore, the presence of these habitats around primary forests may support the ecological need of some species as they may provide attractive foraging grounds and roosting sites for edge and open species.

Though disturbed vegetation supports a higher diversity of bats, the conversion of pristine forests to human-dominated landscapes may be detrimental to forest specialists, which are sensitive to human disturbances. Therefore, understanding the habitat needs of species and how human-caused disturbance affects the pattern of species diversity and abundance is essential in determining the degree of sensitivity to fragmentation 
and local extinction risk, which in turn could be essential for developing effective species-specific conservation strategies. Furthermore, the observed differences in the bat communities between the two habitat types underscore the significance of maintaining primary forest as a means of avoiding the functional homogenization of the biome by preventing the local extinction of forest species (Cazalis et al., 2020). Finally, the occurrence of at least $10 \%$ of bats recorded in Cameroon in the biome indicates the forest remnant needs to be preserved by the local community as a means of safeguarding the local bat diversity.

\section{DATA AVAILABILITY STATEMENT}

The original contributions presented in the study are included in the article/supplementary material, further inquiries can be directed to the corresponding authors.

\section{ETHICS STATEMENT}

The animal study was reviewed and approved by the Cameroon Ministry of Scientific Research and Innovation permit (Ref: 0000011/MINRESI/B00/C00/C10/C14).

\section{REFERENCES}

Abernathy, K. A., Coad, L., Taylor, G., Lee, M. E., and Maisels, F. (2013). Extent and ecological consequences of hunting in Central African rainforests in the twenty-first century. Philos. Trans. R. Soc. B 368:20120303. doi: 10.1098/rstb. 2012.0303

Alpert, P. (1993). Conserving biodiversity in Cameroon. Ambio 22, 44-53.

Anthony, E. L. P. (1988). “Age determination in bats," in Ecological and Behavioral Methods for the Study of Bats, ed. T. H. Kunz (Washington, DC: Smithsonian Institution Press), 47-58.

Atagana, P. J., Bakwo Fils, E. M., Waghiiwimbom, M. D., Tsague, K. J. A., and Kekeunou, S. (2018). The bat fauna of the Mpem and Djim National Park, Cameroon (Mammalia Chiroptera). Biodivers. J. 9, 241-254. doi: 10.1177/ 19400829211010360

Baagøe, H. J. (1977). Age determination in bats (Chiroptera). Vidensk Meddr Dansk Naturhist Foren 140, 53-92.

Bakwo Fils, E. M. (2009). Inventaire des chauves-souris de la réserve de biosphère du Dja. Cameroun Le Véspère 2, 11-20.

Barber, C. P., Cochrane, M. A., Souza, C. M., and Laurance, W. F. (2014). Roads, deforestation, and the mitigating effect of protected areas in the Amazon. Biol. Conserv. 177, 203-209. doi: 10.1016/j.biocon.2014.07.004

Bates, P., Thong, V. D., and Bumrungrsi, S. (2005). Voucher Specimen Preparation: Bats. Sevenoaks: Harrison Institute.

Bergallo, G. H., Esbérard, C., Mello, M. A. R., Lins, V., Mangolin, R., Melo, G. S. S., et al. (2003). Bat species richness in atlantic forest: what is the minimum sampling effort? Biotropica 35, 278-288. doi: 10.1111/j.1744-7429. 2003.tb00286.x

Bergl, R. A., Oates, J. F., and Fotso, R. (2007). Distribution and protected area coverage of endemic taxa in West Africa's Biafran forests and highlands. Bio. Conserve. 134, 195-208. doi: 10.1016/j.biocon.2006.08.013

Brose, U., and Martinez, N. D. (2004). Estimating the richness of species with variable mobility. Oikos 105, 292-300. doi: 10.1111/j.0030-1299.2004.12 884.x

Campbell, S. (2009). So long as it's near water: variable roosting behavior of the large-footed myotis (Myotis macropus). Aust. J. Zool. 57, 89-98.

\section{AUTHOR CONTRIBUTIONS}

E-MB and BB designed the study. MM, DM, AG-D, and JT conducted the fieldwork. MM and E-MB analyzed the data and wrote the manuscript. All authors contributed to the article and approved the submitted version.

\section{FUNDING}

Rufford Small Grant UK supported this research financially (Grant Ref: 19621-1). IDEA WILD provided fieldwork material.

\section{ACKNOWLEDGMENTS}

The authors wish to express their deepest gratitude to the inhabitants of Bokwango and Bakingili villages for providing porters and guides who among other things helped with security and the deployment of mist nets. The authors thank the village chiefs of Pastral, Bouroukou, Ekanang, Loulou, and Melong who showed hospitality and cooperation during our stay in their different localities. The authors are grateful to the Cameroon Ministry of Scientific Research and Innovation for providing a research permit (Ref: 0000011/MINRESI/B00/C00/C10/C14).

Cazalis, V., Prince, K., Mihoub, J.-B., Kelly, J., Butchart, S. H. M., and Rodrigues, A. S. L. (2020). Effectiveness of protected areas in conserving tropical forest birds. Nat. Commun 11:4461.

Clarke, K. R. (1993). Non-parametric multivariate analyses of changes in community structure. Austral Ecol. 18, 117-143. doi: 10.1111/j.1442-9993. 1993.tb00438.x

Cleary, K. A., Waits, L. P., and Finegan, B. (2016). Agricultural intensification alters bat assemblage composition and abundance in a dynamic Neotropical landscape. Biotropica 48, 667-676.

Coleman, J. L., and Barclay, R. M. R. (2012). Urbanization and the abundance and diversity of prairie bats. Urban Ecosyst. 15, 87-102. doi: 10.1007/s11252-0110181-8

Collar, N. J., and Stuart, S. M. (1988). Key Forest For Threatened Birds In Africa. Cambridge: International Council for Bird Preservation. (Monogr. 3).

Colwell, R. K. (2013). Estimate S, Version 9; Statistical Estimation Of Species Richness And Shared Species From Samples. User's Guide And Application. Available online at: http://purl.oclc.org/estimates (accessed February 11, 2020).

Colwell, R. K., and Coddington, J. A. (1994). Estimating terrestrial biodiversity through extrapolation. Philos. Trans. R. Soc. Lond. Ser. B Biol. Sci. 345, 101-118. doi: 10.1098/rstb.1994.0091

Cosson, J., Pons, J., and Masson, D. (1999). Effects of forest fragmentation on frugivorous and nectarivorous bats in French Guiana. J. Trop. Ecol. 15, 515-534. doi: 10.1017/S026646749900098X

Cronin, D. T., Moses, B., Libalah, M. B., Richard, A., Bergl, R. A., and Hearn, G. W. (2014). Biodiversity and conservation of tropical montane ecosystems in the gulf of guinea, West Africa. Arct. Antarct. Alp. Res. 46, 891-904. doi: 10.1657/1938-4246-46.4.891

Debinski, D. M., and Holt, R. D. (2000). A survey and overview of habitat fragmentation experiments. Biol. Conserv. 14, 342-355. doi: 10.1046/j.15231739.2000.98081.x

Denzinger, A., and Schnitzler, H.-U. (2013). Bat guilds, a concept to classify the highly diverse foraging and echolocation behaviors of microchiropteran bats. Front. Physiol. 4:164. doi: 10.3389/fphys.2013.00164

Devictor, V., Julliard, R., Jiguet, F., and Couvet, D. (2008). Distribution of specialist and generalist species along spatial gradients of habitat disturbance and fragmentation. Oikos 117, 507-514. doi: 10.1111/j.2008.0030-1299.16215.x 
Doumenge, C., Gilmour, D., Ruiz Pérez, M., and Blockhus, J. (1995). “Tropical montane cloud forests: conservation status and management issues," in Tropical Montane Cloud Forests, eds L. S. Hamilton, J. O. Juvik, and F. N. Scatena (New York, NY: Springer-Verlag), 24-37. doi: 10.1007/978-1-4612-2500-3_2

Duchamp, J. E., and Swihart, R. K. (2008). Shifts in bat community structure related to evolved traits and features of human-altered landscapes. Landsc. Ecol. 23, 849-860. doi: 10.1007/s10980-008-9241-8

Duchamp, J. E., Arnett, E. B., Larson, M. A., and Swihart, R. K. (2007). "Ecological considerations for landscape-level management of bats," in Conservation And Management Of Bats In Forests, eds M. J. Lacki, J. P. Hayes, and A. Kurta (Baltimore, MD: John Hopkins University Press).

Edwards, D. P., Socolar, J. B., Mills, S. C., Burivalova, Z., Koh, L. P., and Wilcove, D. S. (2019). Conservation of tropical forests in the Anthropocene. Curr. Biol. 29, R1008-R1020. doi: 10.1016/j.cub.2019.08.026

Eisentraut, M. (1942). Beitrag zur oekologie kameruner chiropteren. Mitt. Zool. Mus. Berlin 25, 245-273.

Eisentraut, M. (1956). Beitrag zur chiropteren-fauna von kamerun (Westafrika). Zool. Jahrb. Abt. Syst. 84, 505-540.

Eisentraut, M. (1963). Die Wirbeltiere Des Kamerungebirges. Hamburg: Verlag Paul Parey.

Eisentraut, M. (1964). La faune de chiroptères de Fernando Po. Mammalia 28, 529-552.

Eisentraut, M. (1968). Beitrag zur säugetierfauna von kamerun. Bonn. Zool. Beitr. $19,1-14$.

Eisentraut, M. (1973). Die wirbeltierfauna von fernando poo und westkamerun unter besonderer berücksichtigung der bedeutung der pleistozänen klimaschwankung für die heutige faunenverteilung. Bonn. Zool. Monogr. 3, 1-428.

Enang, R., Yerima, B., Kome, G., and Ranst, E. (2019). Short-range-order minerals and dominant accessory properties controlling $\mathrm{p}$ sorption in tropical tephra soils of the cameroon volcanic line. Open J. Soil Sci. 9, 113-139. doi: 10.4236/ ojss.2019.98008

Estrada, A., and Coastes-Estrada, R. (2001). Species composition and reproductive phenology of bats in a tropical landscape at Los Tuxtlas. J. Trop. Ecol. 17, 627-646. doi: 10.1017/S026646740100147X

Estrada, A., and Coates-Estrada, R. (2002). Bats in continuous forest, forest fragments, and in an agricultural mosaic habitat-is-land at Los Tuxlas. Mexico. Biol. Conserv. 103, 237-245. doi: 10.1016/S0006-3207(01)00135-5

Estrada-Villegas, S., Meyer, C. F. J., and Kalko, E. K. V. (2010). Effects of tropical forest fragmentation on aerial insectivorous bats in a land-bridge island system. Biol. Conserv. 143, 597-608. doi: 10.1016/j.biocon.2009.11.009

Fahr, J., and Kalko, E. K. V. (2010). Biome transitions as centres of diversity: habitat heterogeneity and diversity patterns of West African bat assemblages across spatial scales. Ecography 34, 177-195. doi: 10.1111/j.1600-0587.2010.05510.x

Farneda, F. Z., Rocha, R., López-Baucells, A., Groenenberg, M., Silva, I., Palmeirim, J. M., et al. (2015). Trait-related responses to habitat fragmentation in Amazonian bats. J. Appl. Ecol. 52, 1381-1391. doi: 10.1111/1365-2664.12490

Fedden, M. O., and MacLeod, H. L. (1986). "Bat research in western Cameroon," in Conservation of Cameroon Montane Forest: Report of the ICBP Cameroon Montane Forest Survey November 1983-April 1984, ed. S. N. Stuart (Cambridge: International Council for Bird Preservation), 175-195.

Forboseh, P. F., Sunderland, T. C. H., Comiskey, J. A., and Balinga, M. (2011). Tree population dynamics of three altitudinal vegetation communities on Mount Cameroon (1989-2004). J. Mt. Sci. 8, 495-504. doi: 10.1007/s11629-011-2031-9

Fried, J. H., Levey, D. J., and Hogsette, J. A. (2005). Habitat corridors function as both drift fences and movement conduits for dispersing flies. Oecologia 143, 645-651. doi: 10.1007/s00442-005-0023-6

Furey, N. M., Mackie, I. J., and Racey, P. A. (2009). The role of ultrasonic bat detectors in improving inventory and monitoring surveys in Vietnamese karst bat assemblages. Curr. Zool. 55, 327-341. doi: 10.1093/czoolo/55.5.327

Gartlan, S. (1989). La Conservation Des Ecosystèmes Forestiers Du Cameroun. Gland: IUCN.

Gehrt, S., and Chelsvig, J. E. (2003). Bat activity in an urban landscape: patterns at the landscape and microhabitat scale. Ecol. Appl. 13, 939-950. doi: 10.1890/025188

Geldmann, J., Barnes, M., Coad, L., and Craigie, I. (2013). Effectiveness of terrestrial protected areas in reducing habitat loss and population declines. Biol. Conserv. 161, 230-238. doi: 10.1016/j.biocon.2013.02.018
Gentry, A. H. (1995). "Patterns of diversity and floristic composition in neotropical rain forests," in Biodiversity And Conservation Of Neotropical Montane Forests, eds S. P. Churchill, H. Balslev, E. Forero, and J. L. Luteyn (Bronx, NY: New York Botanical Garden Press), 103-126.

Gibbs, H., Ruesch, A. S., Achard, F., and Clayton, M. K. (2010). Les forêts tropicales étaient les principales sources de nouvelles terres agricoles dans les années 1980 et 1990. Actes Acad. Nat. Sci. 107, 16732-16737.

Glover, M. A., and Altringham, J. D. (2008). Cave selection and use by swarming bat species. Biol. Conserv. 141, 1493-1504. doi: 10.1016/j.biocon.2008. 03.012

Gorresen, P. M., and Willig, M. R. (2004). Landscape responses of bats to habitat fragmentation in Atlantic forest of paraguay. J. Mammal. 85, 688-697. doi: 10.1644/BWG- 125

Gountié Dedzo, M., Nono, A., Njonfang, E., Kamgang, P., Tefogoum, G. Z., Dongmo, A. K., et al. (2011). Le volcanisme Ignimbritique Des Monts Bamboutos Et Bamenda (Ligne Du Cameroun, Afrique Centrale) : signification Dans La Genèse Des Caldeiras. Bulletin de Linstitut Scientifique. Rabat: Section Sciences De La Terre. 1-15.

Gray, C. L., Hill, S. L., Newbold, T., Hudson, L. N., Börger, L., Contu, S., et al. (2016). Local biodiversity is higher inside than outside terrestrial protected areas worldwide. Nat. Commun. 7:12306. doi: 10.1038/ncomms12306

Grindal, S. D., Morissette, J. L., and Brigham, R. M. (1999). Concentration of bat activity in riparian habitats over an elevational gradient. Can. J. Zool. 77, 972-977. doi: 10.1139/cjz-77-6-972

Hamilton, L. S., Juvick, J. O., and Scalena, F. (1994). Tropical Montane Cloud Forest. New York, NY: Springer-Verlag.

Hamilton, L. S., Juvik, J. O., and Scatena, F. N. (2012). Tropical Montane Cloud Forests. Berlin: Springer Science \& Business Media.

Hammer, Ø, Harper, D. A. T., and Ryan, P. D. (2001). PAST: paleontological statistics software package for education and data analysis. Palaeontol. Electron. 4:9.

Happold, M., and Happold, D. C. D. (2013). Mammals of Africa Volume IV: Hedgehogs, Shrews, And Bats. London: Blooms -bury Publishing.

Henle, K., Davies, K. F., Kleyer, M., Margules, C., and Settele, J. (2004). Predictors of species sensitivity to fragmentation. Biodivers. Conserv. 13, 207-251. doi: 10.1023/B:BIOC.0000004319.91643.9e

Hill, J. E. (1968). Bats from the Cameroons, with the description of a new species of Pipistrellus. Bonn. Zool. Beitr. 19, 43-48.

Hodgkison, R., Balding, S. T., Zubaid, A., and Kunz, T. H. (2004). Temporal variation in the relative abundance of fruit bats (Megachiroptera: Pteropodidae) in relation to the availability of food in a lowland Malaysian Rain Forest. Biotropica 36, 522-533. doi: 10.1111/J.1744-7429.2004.TB00347.X

Ineich, I., LeBreton, M., Lhermitte-Vallarino, N., and Chirio, L. (2015). The reptiles of the summits of Mont Oku and the Bamenda Highlands, Cameroon. Amphib. Reptile Conserv. 9, 15-38.

Jones, G., Jacobs, D. S., Kunz, T. H., Willig, M. R., and Racey, P. A. (2009). Carpe noctem: the importance of bats as bioindicators. Endanger. Species Res. 8, 93-115. doi: 10.3354/esr00182

Jung, K., Kaiser, S., Böhm, S., Nieschulz, J., and Kalko, E. K. V. (2012). Moving in three dimensions: effects of structural complexity on occurrence and activity of insectivorous bats in managed forest stands. J. Appl. Ecol. 49, 523-531. doi: 10.1111/j.1365-2664.2012.02116.x

Kalka, M. B., Smith, A. R., and Kalko, E. K. V. (2008). Bats limit arthropods and herbivory in a tropical forest. Science 320:71. doi: 10.1126/science.1153352

Kalko, E. K. V., and Handley, C. O. (2001). Neotropical bats in the canopy: diversity,community structure, and implications for conservation. Plant Ecol. 153, 319-333. doi: 10.1023/a:1017590007861

Kalko, E. K., Estrada-Villegas, S., Schmidt, M., Wegmann, M., and Meyer, C. F. (2008). Flying high - assessing the use of the aerosphere by bats. Integr. Comp. Biol. 48, 60-73. doi: 10.1093/icb/icn030

Kengni, L., Tekoudjou, H., Tematio, P., Tedonkeng, E. P., Tankou, C. M., Lucas, Y., et al. (2009). Rainfall variability along the southern flank of the bamboutos mountain (West-Cameroon). J. Cameroon Acad. Sci. 8, 45-52.

Kessler, M., and Kluge, J. (2008). Diversity and endemism in tropical montane forests-from patterns to processes. Biodivers. Ecol. Ser. 2, 35-50.

Kirsten, I., and Klomp, N. I. (1998). Microchiroptera in urban, rural and forest areas of southern NSW. Australas Bat. Soc. Newsl. 11, 28-30. 
Klingbeil, B. T., and Willig, M. R. (2009). Guild-specific responses of bats to landscape composition and configuration in the fragmented Amazonian rainforest. J. Appl. Ecol. 46, 203-213.

Körner, C., and Ohsawa, M. (2006). "Mountain systems," in Ecosystem and Human Well-Being: Current State And Trends, eds R. Hassan, R. Scholes, N. Ash, and Millennium Ecosystem Assessment (Washington, DC: Island Press), 681-716.

Kunz, T. H., and Parsons, S. (2009). Ecological and Behavioral Methods for the Study of Bats, 2nd Edn. Baltimore, MD: Johns Hopkins University Press.

Laurance, W. F., Useche, D. C., Rendeiro, J., Kalka, M., and Bradshaw, C. J. A. (2012). Averting biodiversity collapse in tropical forest protected areas. Nature 489, 290-294. doi: 10.1038/nature11318

Law, B. S., Anderson, J., and Chidel, M. (1999). Bat communities in a fragmented forest landscape on the south-west slopes of New South Wales, Australia. Biol. Conserv. 88, 333-345. doi: 10.1016/S0006-3207(98)00118-9

Law, B. S., Chidel, M., and Tap, P. (2011). "Bat activity in ephemeral streambeds in the Pilliga forests: clarifying the importance of flyways and buffer widths in open forest and woodland," in The Biology and Conservation of Australian Bats, eds B. Law, P. Eby, D. Lunney, and L. Lumsden (Mosman, NSW: Royal Zoological Society of NSW).

Lawson, D. P. (1993). The reptiles and amphibians of the Korup National Park Project, Cameroon. Herpetol. Nat. Hist. 1, 27-90.

Letouzey, R. (1985). Notice Phytogéographique Du Cameroun Au 1:500000. Toulouse: Institut de la Carte Internationale de la végétation.

Linder, J. M., and Oates, J. F. (2011). Differential impact of bushmeat hunting on monkey species and implications for primate conservation in Korup National Park, Cameroon. Biol. Conserv. 144, 738-745. doi: 10.1016/j.biocon.2010. 10.023

Loeb, S. C., Post, C. J., and Hall, S. T. (2009). Relationship between urbanization and bat community structure in national parks of the southeastern U.S. Urban Ecosyst. 12, 197-214. doi: 10.1007/s11252-008-0075-6

MacSwiney, M. C., Clarke, F. M., and Racey, P. A. (2008). What you see is not what you get: The role of ultrasonic detectors in increasing inventory completeness in Neotropical bat assemblages. J. Appl. Ecol. 45, 1364-1371. doi: 10.1111/j.13652664.2008.01531.x

Magurran, A. E. (1988). Ecological Diversity and Its Measurement. London: Croom Helm.

Magurran, A. E. (2004). Measuring Biological Diversity. Oxford: Blackwell Publishing.

Maisels, F., Keming, E., Kemei, M., and Toh, C. (2001). The extirpation of large mammals and implications for montane forest conservation: the case of the Kilum-Ijim Forest, North-west Province, Cameroon. Oryx 35, 322-331. doi: 10.1046/j.1365-3008.2001.00204.x

Manfothang, D. E., Bakwo Fils, E.-M., Mongombe, A. M., and Tchuenguem, F. F.N. (2020). Diversity of bats (Mammalia: Chiroptera) along an altitudinal gradient in the western region of Cameroon. Bonn. Zool. Bull. 69, 45-54.

Manfothang, D., Bakwo Fils, E.-M., Mongombe, M. A., Atagana, P. J., and Tchuenguem, F. F.-N. (2021). Diversity pattern of bats (Mammalia: Chiroptera) in a modified tropical environment in the western region of Cameroon. Afr. Zool. 56, 133-145.

McCune, B., and Grace, J. B. (2002). Analysis Of Ecological Communities. Gleneden Beach, OR: MJM Software Design.

Medellín, R. A., Equihua, M., and Amin, M. A. (2002). Bat diversity and abundance as indicators of disturbance in neotropical rainforests. Conser. Biol. 14, 16661675. doi: 10.1046/j.1523-1739.2000.99068.x

Megevand, C., Mosnier, A., Hourticq, J., Sanders, K., Doetinchem, N., and Streck, C. (2013). Deforestation Trends in the Congo Basin: Reconciling Economic Growth and Forest Protection. Washington, DC: The World Bank, doi: 10.1596/ 978-0-8213-9742-8

Meyer, C. F. J., Aguiar, L. M. S., Aguirre, L. F., Baumgarten, J., Clarke, F. M., Cosson, J.-F., et al. (2011). Accounting for detectability improves estimates of species richness in tropical bat surveys. J. Appl. Ecol. 48, 777-787. doi: 10.1111/J.1365-2664.2011.01976.X

Meyer, C. F., Struebig, M. J., and Willig, M. R. (2016). "Responses of tropical bats to habitat fragmentation, logging, and deforestation," in Bats in the Anthropocene: Conservation of Bats in a Changing World, eds C. Voigt and T. Kingston (Cham: Springer), 63-103.
Meyer, J. P., Hecht, T., Gill, H., and Toplonytsky, L. (2010). Person-organization (culture) fit and employee commitment under conditions of organizational change: a longitudinal study. J. Vocat. Behav. 76, 458-473. doi: 10.1016/j.jvb. 2010.01.001

Moir, M., Richards, L. R., Rambau, R. V., and Cherry, M. I. (2021). Functional diversity and trait filtering of insectivorous bats relate to forest biogeography and fragmentation in South Africa. J. Biogeogr. 48, 1170-1182. doi: 10.1111/jbi. 14069

Monadjem, A., Demos, T. C., Dalton, D. L., Webala, P. W., Musila, S., Peterhans, J. C. K., et al. (2021). A revision of pipistrelle-like bats (Mammalia: Chiroptera: Vespertilionidae) in East Africa with the description of new genera and species. Biol. J. Linn. Soc. 191, 1114-1146. doi: 10.1093/zoolinnean/zlaa087

Monadjem, A., Richards, L., and Denys, C. (2016). An African bat hotspot: the exceptional importance of Mount Nimba for bat diversity. Acta Chiropt. 18, 359-375. doi: 10.3161/15081109ACC2016.18.2.005

Monadjem, A., Taylor, P. J., Cotterill, F. P. D., and Schoeman, M. C. (2010). Bats of Southern and Central Africa: a Biogeographic and Taxonomic Synthesis. Johannesburg: University of the Witwatersrand Press.

Mongombe, M. A., Bakwo Fils, E.-M., and Tamesse, J. L. (2019). Diversity and altitudinal distribution of bats (Mammalia: Chiroptera) on Mount Cameroon. Trop. Zool. 32, 166-187. doi: 10.1080/03946975.2019.1680077

Mongombe, M. A., Bakwo Fils, E.-M., and Tamesse, J. L. (2020). Annotated checklist of bats (Mammalia: Chiroptera) of Mount Cameroon, southwestern Cameroon. Zoosystema 42, 435-466. doi: 10.5252/zoosystema

Morrison, D. W. (1978). Lunar phobia in a Neotropical fruit bat (Artibeus jamaicensis). Anim. Behav. 26, 852-855. doi: 10.1016/0003-3472(78)90151-3

Mugagga, F., Kakembo, V., and Buyinza, M. (2012). Land-use changes on the slopes of Mount Elgon and the implications for the occurrence of landslides. Catena 90, 39-46. doi: 10.1016/j.catena.2011.11.004

Myers, J. A., Chase, J. M., Crandall, R. M., and Jiménez, I. (2015). Disturbance alters beta-diversity, but not the relative importance of community assembly mechanisms. J. Ecol. 103, 1291-1299. doi: 10.1111/1365-2745.12436

Myers, N. (1991). Tropical deforestation and climatic change: the conceptual background. Clim. Change 19, 1-2. doi: 10.1007/BF00142208

Myers, N., Mittermeier, R. A., Mittermeier, C. G., Da Fonseca, G. A. B., and Kant, J. (2000). Biodiversity hotspots for conservation priorities. Nature 403, 853-858. doi: 10.1038/35002501

Oates, J. F., Bergl, R. A., and Linder, J. M. (2004). Africa's gulf of guinea forests: biodiversity patterns and conservation priorities. Adv. Appl. Biodivers. Sci. 6:90.

Oksanen, J., Blanchet, F. G., Friendly, M., Kindt, R., Legendre, P., Mcglinn, D., et al. (2018). Community Ecology Package. R Package Version 2, 5-2. Available online at: https://CRAN.R-project.org/package=vegan (accessed January 2, 2020).

Olson, D. M., Dinerstein, E., Wikramanayake, E. D., Burgess, N. D., Powell, G. V. N., Underwood, E. C., et al. (2001). Terrestrial ecoregions of the world: a new map of life on Earth: a new global map of terrestrial ecoregions provides an innovative tool for conserving biodiversity. Bioscience 51, 933-938.

Patterson, B. D., and Webala, P. W. (2012). Keys to the bats (Mammalia: Chiroptera) of East Africa. Fieldiana Life Earth Sci. 6, 1-160. doi: 10.3158/21585520-12.6.1

Payton, R. W. (1993). Ecology, Altitudinal Zonation and Conservation of Tropical Rainforest of Mt Cameroon. Report to the Overseas Development Administration. London, 251.

Pielou, E. C. (1969). An Introduction to Mathematical Ecology. New York, NY: Wiley.

Pinto, N., and Keitt, T. (2008). Scale-dependent responses to forest cover displayed by frugivore bats. Oikos 117, 1725-1731. doi: 10.1111/j.1600-0706.2008.1 6495.x

Ramos Pereira, M. J., Marques, J. T., Santana, J., Santos, C. D., Valsecchi, J., de Queiroz, H. L., et al. (2009). Structuring of Amazonian bat assemblages: the roles of flooding patterns and floodwater nutrient load. J. Anim. Ecol. 78, 1163-1171. doi: 10.1111/j.1365-2656.2009.01591.x

Razgour, O., Kasso, M., Santos, H., and Juste, J. (2020). Up in the air: threats to Afromontane biodiversity from climate change and habitat loss revealed by genetic monitoring of the Ethiopian Highlands bat. Evol. Appl. 14, 794-806. doi: $10.1111 /$ eva.13161

Schnitzler, H.-U., and Kalko, K. M. V. (2001). Echolocation by insect-eating bats. BioScience 51, 557-569. doi: 10.1641/0006-3568(2001)051[0557:ebieb]2.0.co;2 
Schulze, M. D., Seavy, N. E., and Witacre, D. F. (2000). A comparison of Phyllostomid bat assemblages in undisturbed Neotropical forest and forest fragments of a slash-and-burn farming mosaic in Petén, Guatemala. Biotropica 32, 174-184. doi: 10.1111/j.1744-7429.2000.tb00459.x

Sikes, R. S., and The Animal Care and Use Committee of the American Society of Mammalogists (2016). Guidelines of the American Society of Mammalogists for the use of wild mammals in research and education. J. Mammal. 97, 663-688. doi: 10.1093/jmammal/gyw078

Silva, C. R., and Bernard, E. (2017). Bioacoustics as an important complementary tool in bat inventories in the caatinga drylands of Brazil. Acta Chiropt. 19, 409-418. doi: 10.3161/15081109ACC2017.19.2.017

Simpson, E. H. (1949). Measurement of diversity. Nature 163:688. doi: 10.1038/ $163688 \mathrm{a} 0$

Stattersfield, A. J., Crosby, M. J., Long, A. J., and Wege, D. C. (1998). Endemic Bird Areas of the World: Priorities for Biodiversity Conservation: BirdLife Conservation Series No. 7. Cambridge: Bird Life International.

Stevens, R. D., Willig, M. R., and Fox, I. G. (2004). Comparative community ecology of bats from eastern Paraguay: taxonomic, ecologic, and biogeographic perspectives. J. Mammal. 85, 698-704.

Straube, F. C., and Bianconi, G. V. (2002). Sobre a grandeza e a unidade para estimar o esforço de captura com utilização de redes-de-neblina. Chiropt. Neotrop. 8, 150-152.

Stuart, S. N. (1986). Conservation of Cameroon Montane Forests. Cambridge: International Council for Bird Preservation.

Threlfall, C. G., Law, B., and Banks, P. B. (2012). Influence of landscape structure and human modifications on insect biomass and bat foraging activity in an urban landscape. PLoS One 7:e38800. doi: 10.1371/journal.pone.00 38800

Vaughan, T. A. (1977). Foraging behaviour of the giant leaf-nosed bat (Hipposideros commersoni). Afr. J. Ecol. 15, 237-249.

Waghiiwimbom, M. D., Eric-Moise, B. F., Jules, A. P., Joseph, T. K., and Tamesse, J. L. (2019). Diversity and community structure of bats (Chiroptera) in the Centre Region of Cameroon. Afr. J. Ecol. 58, 211-226. doi: 10.1111/aje.12692

Walsh, A. L., and Harris, S. (1996). Foraging habitat preferences of vespertilionid bats in Britain. J. Appl. Ecol 33, 508-518. doi: 10.2307/2404980
Webala, P. W., Mwaura, J., Mware, J. M., Ndiritu, G. G., and Patterson, B. D. (2019). Effects of habitat fragmentation on the bats of Kakamega Forest, western Kenya. J. Trop. Ecol 35, 260-269.

Weber, N., and Fahr, J. (2006). Survey of Endemic And Globally Threatened Bat Species In The Fouta Djallon Plateau For Conservation Priorities In Guinea. Preliminary Project Report - Vantienhovenfoundation:7pp. Available online at: http://www.vantienhovenfoundation.com/uploads/Weber\&Fahr_ preliminary+report.pdf (accessed February 10, 2020).

Weber, N., Kalko, E. K. V., and Fahr, J. (2009). A first assessment of home range and foraging behaviour of the African long-tongued Bat Megaloglossus woermanni (Chiroptera: Pteropodidae) in a heterogeneous landscape within the Lama Forest Reserve Benin. Acta Chiropt. 11, 317-329. doi: 10.3161/ 150811009X485558

Willig, M. R., Presley, S. J., Bloch, C. P., Hice, C. L., Yanoviak, S. P., Diaz, M. M., et al. (2007). Phyllostomid bats of lowland Amazonia: effects of habitat alteration on abundance. Biotropica 39, 737-746. doi: 10.1093/jmammal/ gyz023

Conflict of Interest: The authors declare that the research was conducted in the absence of any commercial or financial relationships that could be construed as a potential conflict of interest.

Publisher's Note: All claims expressed in this article are solely those of the authors and do not necessarily represent those of their affiliated organizations, or those of the publisher, the editors and the reviewers. Any product that may be evaluated in this article, or claim that may be made by its manufacturer, is not guaranteed or endorsed by the publisher.

Copyright (c) 2021 BakwoFils, Mongombe, Manfothang, Gomeh-Djame, Takuo and Bilong. This is an open-access article distributed under the terms of the Creative Commons Attribution License (CC BY). The use, distribution or reproduction in other forums is permitted, provided the original author(s) and the copyright owner(s) are credited and that the original publication in this journal is cited, in accordance with accepted academic practice. No use, distribution or reproduction is permitted which does not comply with these terms. 